\title{
Strącona bogini - Inna od siebie
}

Gabriela Matuszek 


\section{Strącona bogini - Inna od siebie}

Gabriela Matuszek

TEKSTY DRUGIE 2017, NR 5, S. 209-218

DOI: 10.18318/td.2017.5.14

1.

Brygida Helbig ${ }^{1}$, literaturoznawczyni i pisarka mieszkająca w Berlinie, jest dobrze znana zarówno w polskich kręgach literaturoznawczych, jak i czytelniczych, bowiem jej tom opowiadań Enerdowce i inne ludzie znalazł się w finale Literackiej Nagrody Gryfia 2012 roku oraz był nominowany do Nagrody Nike, a powieść Niebko weszła do ścisłej czołówki nominowanych do NIKE 2014. Ta znakomita badaczka i pisarka wiosną 2016 roku otrzymała Złotą Sowę Polonii w kategorii Literatura, czyli tzw. polonijnego Oscara.

Jesienią 2016 roku ukazała się jej nowa powieść, Inna od siebie, poświęcona życiu Marii Komornickiej, która w 1907 roku, w wieku 31 lat, spaliła kobiece suknie i ogłosiła się mężczyzną - Piotrem Włastem. Komornicka vel Piotr Włast przez dziesięciolecia wykluczona z kultury i badań literaturoznawczych, od lat 9o. XX wieku stała

1 Autorka teksty naukowe publikuje pod pełnym nazwiskiem - Brigitta Helbig-Mischewski, literackie jako Brygida Helbig.
Gabriela Matuszek -

profesor tytularny na Wydziale Polonistyki

U). Zajmuje się literaturą przełomu XIX/XX wieku, literaturą najnowszą, polsko-niemieckimi związkami kulturowymi, twórczym pisaniem. Ostatnio wydane książki: Krisen und Neurosen - Das Werk Stanislaw Przybyszewskis in der literarischen Moderne (przeł. D. Gass, Hamburg 2013), Maski idemony wczesnego modernizmu (Kraków 2014), Wiek (nie)męski. Szkice o literaturze i varia (Kraków 2017). Kontakt: gabriela. matuszek@uj.edu.pl 
się ikoną studiów feministycznych. Pisarce poświęcono wiele ważnych rozpraw i książek (m.in. autorstwa Marii Podrazy-Kwiatkowskiej, Marii Janion, Krystyny Kralkowskiej-Gątkowskiej, Katarzyny Zdanowicz, Izabeli Filipiak, Brigitty Helbig-Mischewski oraz przedstawicieli płci męskiej - Edwarda Bonieckiego czy Germana Ritza ${ }^{2}$ ) i dwa utwory literackie³. Twórczością Marii Komornickiej zajmowała się także autorka Innej od siebie, która wiosną 2005 roku opublikowała w Niemczech pracę habilitacyjną Ein Mantel aus Sternenstaub. Geschlechtstransgres und Wahnisnn bei Maria Komornicka, w wersji polskiej rozprawa ukazała się w 2010 roku jako Strącona bogini. Rzecz o Marii Komornickiej ${ }^{4}$.

Dysertacja Helbig-Mischewski zawiera wiele nowatorskich interpretacji utworów Komornickiej, dokonywanych z perspektywy feministycznej, genderowej i psychoanalitycznej. Badaczkę interesują relacje między twórczością i życiem, zawsze jednak traktuje dzieła literackie jako niezależne twory artystyczne, świadoma tego, że nie są one lustrzanym odbiciem biografii, a co najwyżej jej elementem. Jednym z punktów centralnych książki jest próba odpowiedzi na pytanie, jakie mechanizmy kulturowe i psychologiczne doprowadziły do transgresji Marii w Piotra Własta, dlaczego najbliżsi nie potrafili jej pomóc i przyczynili się do jej cierpienia i poniżenia. Podpowiedzi autorka szuka w utworach literackich, listach i innych świadectwach biograficznych. Wykorzystuje metodę badań (anty)psychiatrycznych, zwłaszcza F. Ruppechta,

Por. M. Podraza-Kwiatkowska Tragiczna wolność. O Marii Komornickiej, w tejże Młodopolskie harmonie i dysonanse, PIW, Warszawa 1969; M. Janion Gdzie jest Lemańska? Maria Komornicka in memoriam, w tejże Kobiety i duch inności, Sic!, Warszawa 1996; K. Kralkowska-Gątkowska Cień twarzy. Szkice o twórczości Marii Komornickiej, Wydawnictwo UŚ, Katowice 2002; E.K. Zdanowicz Kto się boi Marii K.?: sztuka i wykluczenie, Gnome, Katowice 2004; I. Filipiak Obszary odmienności. Rzecz o Marii Komornickiej, słowo/obraz terytoria, Gdańsk 2006; E. Boniecki Modernistyczny dramat ciała. Maria Komornicka, Wydawnictwo IBL PAN, Warszawa 1998; G. Ritz Maria Komornicka: Die gefährdete Autorschaft in den Wirren des Geschlechtes. Die widerständige Identität einer Transvestitin, w: Mystifikation, Autorschaft, Original, Hrsg. von S. Frank, R. Lachmann et al., Narr, Tübingen 2001.

3 Wcześniej od powieści Helbig powstał dramat Izabeli Filipiak Księga Em, tchu dom Wydawniczy, Warszawa 2005, który pisała przez pięć lat, w czasie, kiedy przygotowywała rozprawę doktorską, opublikowaną później jako książka Obszary odmienności.

4 Por. B. Helbig-Mischewski Ein Mantel aus Sternenstaub. Geschlechtstransgress und Wahnsinn bei Maria Komornicka, Norderstedt: Books on Demand GmbH 2005; B. Helbig-Mischewski Strqcona bogini. Rzecz o Marii Komornickiej, przeł. K. Długosz, B. Helbig-Mischewski, K. Pukański, Kraków: Universitas 2010. 
który - nawiązując do koncepcji Berta Hellingera ${ }^{5}$ - traktuje psychozę jako fenomen dotyczący rodzinnych zależności na przestrzeni pokoleń. Forma psychozy nie jest przypadkowa, często ma związek ze skrywanymi tajemnicami. Helbig-Mischewski przyznaje, że niektóre urojenia Piotra Własta charakterystyczne są dla świata schizofreników ${ }^{6}$, unika jednak diagnozowania choroby i patologizowania autorki - woli używać kategorii cierpienia. W przemianie i chorobie Komornickiej interesuje ją geneza i ukryty s e n s urojeń.

Polsko-niemiecka badaczka nie stawia tezy (co robi np. Izabela Filipiak ${ }^{7}$ ), że jedną z najważniejszych przyczyn cierpień jest seksualność, w przypadku Komornickiej - być może - homoseksualność. Nie eksponuje specjalnie tego wątku, choć zwraca uwagę na to, że erotyki Komornickiej należą do najbardziej zaskakujących w literaturze polskiej - są przesycone na wskroś męskimi fantazjami, sadomasochistycznymi wizjami i tragicznym uwikłaniem w poczucie winy i kary. Za wtajemniczenie kobiety w świat seksualny musi zapłacić albo kochanek - śmiercią, albo bohaterka - samozniszczeniem ${ }^{8}$.

Dla Helbig-Mischewski zdecydowanie ważniejszy w twórczości Komornickiej jest motyw lęku przed obłędem i ekscesy szaleństwa, które znajduje już we wczesnych utworach pisarki (Szkice, Forpoczty, Biesy). Bohaterki

5 Por. F. Ruppert Verwirrte Seelen. Der verborgene Sinn von Psychosen. Grundzüge einer systematischen Psychotraumatologie, Kösel Verlag, München 2002; por. też m.in. B. Hellinger Praca nad rodzing: metoda Berta Hellingera, przeł A. Ubertowska, Gdańskie Wydawnictwo Psychologiczne, Gdańsk 2004; B. Hellinger Wielki konflikt: od uwikłań rodzinnych do nierozwiq̨zanych konfliktów między narodami, przeł. E. Urbańska, Czarna Owca, Warszawa 2010.

6 B. Helbig-Mischewski zauważa, że w skład urojeń Własta wchodzą elementy charakterystyczne dla świata schizofreników: przekonanie o własnej szczególnej misji, mania prześladowcza, huśtawka między krańcowymi emocjami, dzielenie otoczenia na anioły i demony, potrzeba nieustannego głoszenia prawdy, ponadprzeciętne zainteresowanie eschatologią i sprawami ostatecznym itd. (por. B. Helbig-Mischewski Stracona bogini, s. 526).

7 Izabela Filipiak w swej znakomitej książce snuje wiele interesujących hipotez, bardzo prawdopodobnych, choć z perspektywy lat i braku materiałów - trudnych dziś do udowodnienia. Jedną z nich jest lesbianizm, którego ślady tropi w tekstach literackich (w Halszce) i listach (do Zosi Villaume), rodzinnej biografii (wuj Piotr, chrzestny ojciec Marii Komornickiej, najprawdopodobniej był homoseksualistą), zakładając równolegle, że mogła nie być lesbijką, lecz przez środowisko mogła być jako taka postrzegana. Zastanawia ją poetyka insynuacji, która towarzyszyła pisarce właściwie od jej debiutu, a która przejawiała się nie tylko w negatywnych recenzjach jej utworów (podkreślających "męski” talent autorki), ale także w - celowym czy przypadkowym? - zestawianiu obok lub w miejsce jej utworów tekstów polemicznych bądź ośmieszających Komornicką.

8 Por. B. Helbig-Mischewski Strącona bogini, s. 377-481. 
młodziutkiej Komornickiej rozwijają wielkie projekty życiowe, ale ulegają „obłędowi”, zanim uda im się je zrealizować. . Helbig-Mischewski, analizując liryczną i konfesyjną prozę autorki Biesów, śledzi zapisy społecznego i psychicznego wykluczenia, poczucia wyrzucenia z łona świata i manii prześladowczej skierowanej ku innym i ku samej sobie - bohaterki Komornickiej często prześladują same siebie i są same dla siebie wrogiem. Najmocniejszym zapisem poczucia obcości, balansowania na granicy samobójstwa i obłędu są oczywiście Biesy, w których bohaterka „zjada własne tkanki”, „pożera własną duszę". Niewykluczone, że Komornicka przemyciła w tej prozie zmetaforyzowany obraz anoreksji, ,jadłowstrętu psychicznego", albo raczej bulimii1" z jej fazami głodu, „objadania się byle czym, wstrętu, wstydu i wymiotów, będących protestem przeciwko niewłaściwemu pokarmowi, który podsuwa świat, a także wynikiem braku akceptacji ze strony środowiska"11. Bohaterka Biesów czuje, że coś z nią jest "nie tak”, że jest pokawałkowana, rozproszona, pozbawiona scalającej podmiotowości, zanurzona w chaotycznym niebycie, że jest... „niedorodzona” - poroniony płód, który nie ma prawa żyć, ponieważ świat nie pragnie dialogu z odmieńcem.

Interesujące jest zarazem to, że kobiety we wczesnych utworach Komornickiej mają silną feministyczną samoświadomość. Nienawidzą presji zewnętrznej, zwłaszcza ubezwłasnowolnienia przez ojców i mężów, małżeństwo uznają za rodzaj więzienia (a nawet piekła). Kontestują jawnie prawo ojca i protestują przeciwko patriarchalnym ograniczeniom, które blokują możliwość uwolnienia ich witalności i zaspokojenie głodu wiedzy, mają wielką potrzebę aktywnej konfrontacji ze światem i nieujarzmioną żądzę życia. Odważnie buntują się przeciwko patriarchalnemu gorsetowi, nałożonemu jak im się zdaje - przez świat męski, ale próby rozerwania kajdan kończą się klęską oraz wymierzoną sobie karą i poczuciem winy.

Kobiecy podmiot czuje się bowiem zablokowany, zignorowany, uwięziony i osaczony - wygnany z kultury. Jest ofiarą społecznego „systemu okaleczania", za jaki należy uznać wychowanie kobiet w patriarchalnym społeczeństwie. Reakcją na krzywdę jest masochistyczna autoagresja i samozniszczenie. To one czują się winne, katują się i szydzą z siebie. Komornicka i jej bohaterki są świetną ilustracją tezy Elisabeth Bronfen, że emancypacyjny protest

Por. tamże, s. 181.

10 Tę tezę postawiła także Filipiak w książce Obszary odmienności, s. 311.

11 B. Helbig-Mischewski Strq̨cona bogini, s. 348. 
podszyty bywa - pochodzącą z tradycyjnych wzorców literatury i kultury androcentrycznej - paralelizacją kobiet z nieobliczalnością, szaleństwem i śmiercią oraz tendencją do „zabijania kobiet” w sztuce ${ }^{12}$.

Młodziutka Maria Komornicka (przypomnijmy, że wczesne utwory pisała w wieku zaledwie 14-18 lat) była postrzegana jako najodważniejsza i najbardziej wyemancypowana artystka (udział w Forpocztach, skandale towarzyskie: wyjazd z Jellentą, mieszkanie z Nałkowskimi, małżeństwo z Lemańskim itp.). Związku z patriarchatem nigdy jednak nie uda jej się przeciąć. Wręcz przeciwnie. Uwznioślająca idea Rodu, która zacznie kiełkować w jej myśli i twórczości jeszcze przed przemianą, a którą rozwinie Piotr Włast, jego najdoskonalsze ucieleśnienie, mogła być rezultatem pragnienia, by wyjść z roli poniżanej i podporządkowanej, i przejść na stronę wiedzy i władzy. Badaczka słusznie podkreśla, że ogłoszenie się mężczyzną mogło być zastępczym samobójstwem i narodzeniem się na nowo w „lepszej” tożsamości, na dodatek „wyczyszczonej” od złych doświadczeń (także seksualnych) przeszłości. Mogło być również wynikiem psychicznych zaburzeń, rozpaczliwym wołaniem o pomoc, zemstą na rodzinie, zamanifestowaniem płci zgodnej z wewnętrznym odczuciem czy nawet "gestem ironicznym", podobnym do wyrwania sobie wszystkich zębów.

\section{2.}

Jaką powieść może napisać badaczka twórczości Komornickiej/Piotra Własta, rekonstruując życie osoby, którą dobrze zna, gdyż z jej tekstami obcuje od wielu lat? Czy i na ile uda się porzucić naukowy warsztat i na fundamencie posiadanej wiedzy wykreować wyobraźnią autonomiczny powieściowy świat? Brygida Helbig nie ukrywa przed czytelnikiem, że napisała dysertację o Marii Komornickiej, ale TA książka ma być inna, ponieważ publikacje naukowe przyciągają tylko... kurz w bibliotekach. Nie zasłania swej obecności w powieści i pracy własnej fantazji („Widzę to jak na ekranie”13), choć ta obecność jest dyskretna i służy wyłącznie uwiarygodnieniu opowieści. W powieści Helbig Inna od siebie materia literacka podporządkowana jest wprawdzie faktom: „Obejrzeć wszystko razem z nim. Nie za dużo fantazjować, bo nie

12 Por. E. Bronfen Weiblichkeit und Repräsentation - aus der Perspektive von Semiotik und Psychoanalyse, w: Genus: Zur Geschlechterdifferenz in den Kulturwissenschaften, Hrsg. von H. Bußman, R. Hof, Verlag Alfred Kröner, Stuttgart 1995, s. 408-445.

13 Tamże, s. 28. 
ma takiej potrzeby. Opierać się na tym, co o Piotrze pisali świadkowie. Na pozostawionych przez niego tekstach, rozmowach z członkami rodziny ${ }^{14}$, ale kunszt jej wykorzystania i oryginalność narracji czynią tę opowieść pasjonującą. Wyobraźnia autorki szkielet zdarzeń ubiera w intelektualnie przemyślaną, precyzyjnie skomponowaną i przekonującą literacko materię.

Helbig swą powieść złożyła z pięciu części, przedstawiających kolejne etapy biografii autorki Biesów. Zastosowany chwyt rozpoczynania opowieści "od końca" - od ubierania Dziadzia Piotra w trumienne szaty przez siostry zakonne w Izabelinie w roku 1949 (w kobiecą suknię!) buduje napięcie i oczekiwanie czytelnika na wyjaśnienie: jak to się stało? Jak do tego doszło, że życie młodej, fascynującej power women, ustawicznie kontestującej patriarchalny porządek i samą siebie, zamknięte zostało w szpitalu wariatów, a potem skazane na wegetację przy rodzinie najstarszego brata i w domach opieki. Życie biologiczne, nie duchowe, bowiem Piotr Włast, tworząc wizerunek siebie jako wieszcza i mistyka, próbował ocalić godność, a przez pisanie Xsięgi poezji idyllicznej odzyskać własną podmiotowość.

Powieść ma wartką i żywą narrację, prowadzoną charakterystycznym dla prozy Helbig dowcipnym językiem, często balansującym na granicy groteski i ciepłej ironii. Narrację fabularną wspomagają utwory Komornickiej i listy, korespondencja autorki (z zakładami dla psychicznie chorych, w których przebywał Piotr Włast), konteksty kulturowe i historycznoliterackie, a nawet "badania terenowe" miejsc związanych z pisarką; wszystkie te elementy złączone są w organiczną całość.

Wyobraźnia autorki próbuje odtworzyć myśli i uczucia postaci, ich rozmowy, zachowania, okoliczności zdarzeń, opisać przedmioty i krajobrazy, które biorą udział w dramacie; słowem, mamy do czynienia z prozą wyrazistą, zmysłową, pełną celnych i dowcipnych spostrzeżeń i point, i wiarygodną jako opowieść o Marii K. Narracja jest czasem prowadzona z punktu widzenia postaci, najczęściej Marii/Piotra, ale także jej ojca, Augustyna Komornickiego, i brata Jana, dzięki czemu powieść nabiera psychologicznej, a nawet psychoanalitycznej głębi. Interesujące są próby zrozumienia agresywnych zachowań Augustyna, nie tylko w kontekście patriarchalnych wzorów, ale także jego osobistych traumatycznych doświadczeń (m.in. upokorzenia ze

B. Helbig Inna od siebie, W.A.B., Warszawa 2017, s. 20. Chcę zaznaczyć, że tytuł został narzucony przez Wydawnictwo. Brygida Helbig planowała zatytułować swą powieść „Gdzie idziesz naga?”, w nawiązaniu do wiersza Komornickiej, co w moim przekonaniu jest nie tylko literacko bardziej „efektowne", ale także symbolizuje los Marii. 
strony ojczyma). Podobnej (psycho)analizie poddana zostanie matka Marii, zimna i wyniosła piękność - Anna z Dunin-Wąsowiczów, oraz małżeńskie pożycie rodziców pisarki, w którym Augustyn musiał kochać się z „poszatkowanym mięsem", nic więc dziwnego, że „gotuje się w nim wszystko już od dawna. Pokrywka na garnku podskakuje coraz wyżej"15. Sprawy płci w rodzinie Komornickich i Dunin-Wąsowiczów nie były klarowne (oziębłość Anny, tajemniczy stryj Władysław i prawdopodobnie homoseksualny stryj Piotr), trudno się zatem dziwić, że także ten problem szczytować będzie w osobie Marii, choć sama bohaterka powie o sobie: „Ja jestem punktem szczytowym gałęzi swojej. I ród mój nie z królestwa ciała, lecz z królestwa ducha"16. Maria, przeistaczając się w Piotra Własta, zaneguje płeć jako istotny znacznik ludzkiej egzystencji. „A co to za święta krowa ta płeć? A co, zakuci w nią jesteśmy, z nią tożsami?"17, myśli powieściowa Komornicka, a Piotr Włast poda płciowość w wątpliwość: „Co to za różnica - spódnica czy spodnie. Płeć w końcu jest rzeczą umowną"18.

Powieść Helbig unaocznia, jak Maria Komornicka, odrzucając kobiecość na rzecz męskości, wpisuje się w mizoginistyczny dyskurs epoki (czytała wszakże pisma Weiningera i Nieztschego): uzna płeć żeńską za wybrakowaną, gorszą, pozbawioną praw i głosu. Jej młodzieńczy antypatriarchalny bunt - „Nie uznaję władzy ani autorytetu ojca!” - nie zakończył się sukcesem. Zdumiony świat tylko na chwilkę został wytrącony ze swego biegu, by powrócić w utarte od wieków męskie tory i zamknąć niesubordynowane przedstawicielki płci uznanej za piękną w domu wariatów (Helbig przypomina, że Komornicka przeżywała swój dramat w tym samym czasie, co dramat Camille Claudel). Autorka, znawczyni teorii feministycznych i genderowych, trafnie rozpoznaje przyczyny, przebieg i finał tych dramatów, rozgrywających się w czasach, kiedy „kobiety nie były jeszcze całkiem ludźmi” ${ }^{19}$ i ponieważ miały zakneblowane usta, mogły swoje zbuntowane myśli i uczucia jedynie czarną cieczą zapisywać na papierze.

Brygida Helbig próbując wypełniać biograficzne luki, nie przedstawia Komornickiej jako osoby (potencjalnie) homoseksualnej, nie zajmuje jej

\footnotetext{
15 Tamże, s. 99.

16 Tamże, s. 292.

17 Tamże, s. 381.

18 Tamże, s. 31.

19 Tamże, s. 11.
} 
szczególnie epizod przyjaźni z Zosią Villaume, o którym tak dużo w swojej monografii pisała Izabela Filipiak ${ }^{20}$. Choć może szkoda, ponieważ ten okres życia Komornickiej zawiera najwięcej pustych miejsc, więc fantazja pisarki mogłaby tu rozwinąć literackie skrzydła. Ale Helbig woli trzymać się faktów. A może wie więcej, inaczej? Bardziej prawdopodobną przyczyną wyboru męskiej tożsamości są dla niej patologizujące doświadczenia w relacjach z mężczyznami: traumatyczna rola oględzin w cyrkule, być może połączonych $\mathrm{z}$ molestowaniem (literackim zapisem tego zdarzenia miałby być utwór Piotra Własta Intermezzo), seksualnego wykorzystania przez starszego mężczyznę i wielu negatywnych doświadczeń miłosnych. Znaczący w tej materii jest dla Helbig, napisany już przez Piotra Własta, utwór Czartołania i Seni, w którym pojawia się wspomnienie-wyznanie: „Pierwszy jej pąk naderwał Pryap stary, a łasy / [...] / Kochanek marny wtrącił potem do szpitala, / Okryta wstydem... Lancety / Krajały z ciałem serce". Brygida Helbig skłonna byłaby (m.in. za Krystyną Kralkowską-Gątkowską ${ }^{21}$ ) widzieć w tym obrazie sugestię aborcji. Po zakończeniu znajomości z Jellentą Komornicka wyszła za mąż - nie wiadomo, z jakiego powodu - za Jana Lemańskiego, a nazwisko współautora Forpoczt nigdy nie powróci w Xsiędze, co daje do myślenia.

Brygida Helbig podejmuje w Innej od siebie próbę odczytania tekstów literackich Komornickiej i Piotra Własta jako zapisu zdarzeń, które mogły oddawać życiowe doświadczenia bohaterki/bohatera opowieści. W pracy naukowej byłoby to ryzykowne, ale w materii powieściowej znajduje uzasadnienie, pozwala bowiem wyobraźni autorki przekonująco zapełniać miejsca puste. Opowiadanie Staszka posłużyło do przedstawienia relacji Marii i Bolesława Lutomskiego, pierwszego kusiciela ku sztuce i erotyce (znakomita scena dialogowania o Nietzschem na huśtawce), z powieści Halszka zapożyczone zostały sceny fascynacji małym i brzydkim stryjem Piotrem, który otwiera drzwi do „wielkiego świata”, utwór Miłość, pełen egzaltacji i namiętności, łączy autorka z postacią Cezarego Jellenty, a wiersz Czartołania i Seni, już tu przywoływany, traktuje jako zawoalowane wyznanie traumatycznych doświadczeń w życiu Marii. Szczególną uwagę przykuwa wiersz Poznań, w którym Piotr

Zosia Villaume mieszkała w Szczebrzeszynie i była córką doktora Villaume’a (pierwowzór doktora Judyma). Filipiak cytuje korespondencję Marii z Zosią, w której Komornicka zwraca się do młodszej o sześć lat pensjonarki "miła żono”, czyta list „z przerażeniem” i odpowiada, że lepiej pisać "kartkę otwartą" (list z 8 stycznia 1897; I. Filipiak Obszary odmienności, s. 265). Z Po wyjeździe Komornickiej za granicę z Zosią zaprzyjaźniła się Zofia Nałkowska. 
Włast szyfruje okoliczności przemiany („Znajdujemy się w centralnym, kulminacyjnym punkcie. Dlatego musimy uważać"22 , podkreśla narrator), jaka dokonała się w poznańskim hotelu Bazar, gdzie w lipcu 1907 roku, Maria Komornicka spaliła suknie i zażądała męskiego stroju, co spowodowało, że zamiast do Kołobrzegu pojechała do domu wariatów.

Co im to przeszkadzało, że pragnęła się przeistoczyć? Woleliby, żeby popełniła samobójstwo? - pyta powieściowy narrator. Nikomu nie jest już potrzebna: matka zdradziła ją w 1903 roku w Radomiu przy podziale majątku (nie będzie dziedzicem na rodzinnych włościach), Zenon Przesmycki, mistrz i guru, ożenił się z niesympatyczną, pozbawioną fantazji Anielą Hoene, Zosia Nałkowska, rywalka w miłości i literaturze, przemilczała jej nazwisko podczas Zjazdu Kobiet, nie ma pism, które chciałyby ją drukować, ani ludzi, którzy pragnęliby ją kochać - zawalił się jej cały świat, jak sufit Sali posiedzeń dumy państwowej w Petersburgu 15 marca 1907 roku, kiedy Maria poczuła, że coś stało się w jej głowie i jej umysł do normy już nie wróci²3.

Brygida Helbig z empatią stara się zrekonstruować w swej wyobraźni uczucia przepoczwarzającej się płciowo istoty. To, co Komornicka zrobi, postrzegane będzie przez otoczenie jako szaleństwo, ale dla niej samej ma być odrodzeniem. Spali siebie-kobietę, by narodzić się na nowo, w wyższej, duchowej podmiotowości.

Autorka próbowała dociec, jaka była diagnoza choroby Komornickiej, m.in. pisząc listy do zakładów psychiatrycznych, gdzie była leczona, ale na próżno. Z korespondencji Piotra Własta do matki, którą Helbig włącza do swej powieści, wyczytać można ślady urojeń wielkościowych. Obłęd zawsze jest jednak tajemnicą, czasem bywa objawieniem tajemnicy. Brygida Helbig pisze: „Szaleństwo przypisuje się temu, który przerwie milczenie. Naruszy tabu. Wskaże na tajemnicę"24. Lombroso, którego Komornicka w młodości czytała, pokazał przecież, jak obłęd bliski jest geniuszowi (Geniusz i obtąanie ${ }^{25}$ ).

Czy Maria Komornicka/Piotr Włast była genialną pisarką? Takiego pytania powieść Brygidy Helbig nie stawia i na takie pytanie nie odpowiada. Narrator powieści, komentując trzyosobowy kondukt żałobny, złożony z siostry Anieli i dwu zakonnic, który Piotra-Marię odprowadzał na miejsce wiecznego

B. Helbig Inna od siebie, s. 372.

Tamże, s. 362; autorka cytuje wypowiedź Jana Lemańskiego.

Tamże, s. 382.

Mowa o głośnej książce C. Lombroso Geniusz i obłąkanie, przeł. J.L. Popławski, Warszawa 1887. 
spoczynku w Izabelinie pod Warszawą (a które okaże się tymczasowe, bowiem w 1988 roku szczątki pisarki przeniesione zostaną do grobowca rodzinnego na Powązkach), napisze, że kiedyś „ktoś odsunie kamień sprzed jego grobowca"26. Ten kamień przez badaczy został już odsunięty. Dzięki powieści Brygidy Helbig Komornicka/Włast wkracza w szerszą przestrzeń polskiej kultury. Może to więc dobrze, że autorka w swojej książce nie daje upustu nieograniczonej fantazji, że jej wyobraźnia stawia granice, a mimo to tworzy w ich obrębie przekonująca, fascynującą opowieść o tragicznym losie wybitnie uzdolnionej kobiety, którą złamały reguły świata, w którym dane jej było żyć, własna osobowość, a może własne i/albo zakodowane w epoce i rodzinie, szaleństwo.

\section{Abstract}

\section{Gabriela Matuszek}

JAGIELLONIAN UNIVERSITY (CRACOW)

A Dethroned Goddess: Different from Herself

Matuszek examines two books dealing with the life and work of Maria Komornicka, a Polish writer who has recently become a key figure in feminist studies. Both books were written by Brigitta Helbig-Mischewska aka Brygida Helbig. The first, titled Strącona bogini: Rzecz o Marii Komornickiej (A Dethroned Goddess: On Maria Komornicka, 2010), a Polish translation of Helbig-Mischewska's habilitation thesis, is presented in the context of other studies on Komornicka. The second book, titled Inna od siebie (Different from Herself, 2016), is a remarkable novel telling Komornicka's life story. Helbig's twofold take on Komornicka - as a literary scholar and as a writer - is shown to have produced two original and valuable works. Matuszek also suggests that it is thanks to Inna od siebie that Komornicka/Włast is now entering the broader sphere of Polish culture.

\section{Keywords}

Maria Komornicka, Piotr Włast, Brigitta Helbig-Mischewski, Brygida Helbig, Inna od siebie 